\title{
EFFECT OF MONENSIN ON PRODUCTION OF VOLATILE FATTY ACIDS FROM CELLULOSE, HEMICELLULOSES, PECTIN AND STARCH IN MIXED CULTURES OF RUMEN MICROORGANISMS
}

\author{
J. ŠIMU゚NEK, ${ }^{1}$ O. G. SAVKA, ${ }^{2}$ G. I. KALAČNJUK, ${ }^{2}$ S. B. $\mathrm{CHON}^{3}$ and \\ M. MAROUNEK ${ }^{1}$
}

1 Institute of Animal Physiology and Genetics, Czechoslovak Academy of Sciences, 10400 Prague 10-Uhř́něves

2 Ukrainian Research Institute of Physiology and Biochemistry of Farm Animals, Lvov, USSR

${ }^{3}$ Institute of Experimental Biology, Pyongyang, Korean D.P.R.

Received February 15, 1989

\begin{abstract}
Šimůnek J., O. G. Savka, G. I. Kalačnjuk, S. B. Chon, M. Marounek: Effect of Monensin on Production of Volatile Fatty Acids from Cellulose, Hemicelluloses, Pectin and Starch in Mixed Cultures of Rumen Microorganisms. Acta vet. Brno, 58, 1989: 215-223.

In in vitro experiments we studied the effect of monensin on production of volatile fatty acids (VFA) from cellulose, hemicelluloses, pectin and starch in mixed cultures of rumen microorganisms. The following results were obtained:

1. Monensin lowered the concentration of VFA in cultures with cellulose. There were only minor differences in total VFA concentration between monensin-free and monensin-treated cultures with hemicelluloses, pectin and starch.

2. Monensin decreased the molar ratio acetate to propionate in cultures with hemicelluloses, pectin and starch, but increased this ratio in cultures with cellulose.

3. There were no significant differences between monensin from Elanco and its Czechoslovak analogue. Monensin maintained its effect throughout the 3-month experimental period.
\end{abstract}

In vitro, rumen fluid, acetate, propionate, butyrate

Monensin, an ionophore antibiotic, is widely used to improve the feed efficiency and stimulate the body mass gains of ruminants. While considerable research has been reported on how rumen fermentation is affected by monensin, information is limited on how this polyether ionophore affects the fermentation of particular components of plant cell material. Some experiments in vivo and in vitro have shown that monensin decreases the digestibility of fibre and fibrous components (Poos et al. 1979; Henderson et al. 1981; Wallace et al. 1981; Whetstone et al. 1981). Also salinomycin, an ionophore similar to monensin, has been shown to depress the digestibility of fibre (Zinn 1986). However, other authors found only minor 
effect of ionophores on extent of digestion of cellulose (Dinius et al. 1976; Beever et al. 1987), hemicellulose (Dinius et al. 1976), fibre (Faulkner et al. 1985; Kobayashi et al. 1986; Lebzien et al. 1986) and starch (Whetstone et al. 1981; Zinn 1987). Nothing is known about the effect of monensin on digestion of pectin.

In this study we determined the effect of monensin on production of volatile fatty acids (VFA) from four principal plant polysaccharides in experiments in vitro. We were particularly interested in the effect of monensin on the molar ratio acetate : : propionate in VFA formed during substrate decomposition, as it is known that the decreased molar ratio of acetate to propionate is the most consistent observation upon the monensin action in the rumen. We also compared monensin from Elanco Products Co. (USA) with the Czechoslovak analogue supplied by SPOFA and ascertained the effect of two months adaptation of inocula donors to monensin.

\section{Materials and Methods}

\section{Inocula}

Two fistulated wethers served as a source of rumen contents. The wethers were fed on a commercial concentrate $(0.5 \mathrm{~kg})$ and meadow hay ad libitum. The animals were fed twice a day. Samples of rumen contents were taken two hours after the morning feed (average $\mathrm{pH}=6.56$ ). In experiments with starch rumen fluid was used instead of rumen contents. Rumen fluid was prepared from whole rumen contents by straining through two layers of cheese cloth.

There are reports on the adaptation of rumen microorganisms to ionophores (de Jong and Berschauer 1983; Mackie et al. 1984). The same wethers were therefore adapted to $60 \mathrm{mg}$ of monensin SPOFA / day for two months.

\section{Incubations}

Incubations were carried out in $300 \mathrm{ml}$ serum bottles, closed by rubber bungs with ports for gas entry and exit and for sampling. Whole rumen contents or rumen fluid $(50 \mathrm{ml})$ were diluted with McDougall buffer $(100 \mathrm{ml})$, which contained sources of nitrogen (total $0.45 \mathrm{~g} \mathrm{~N} / 1$ ), vitamins and trace elements. To provide the anaerobiosis, we used an addition of amorphous $\mathrm{FeS}$ into the medium and $\mathrm{O}_{2}$-free $\mathrm{CO}_{2}$ atmosphere. The incubation time and amount of substrates was chosen with respect to the different rates of breakdown of particular carbohydrates (Marounek et al. 1985). Cultures were incubated without $\mathrm{pH}$ control. The $\mathrm{pH}$ fell from 7.0-7.2 to about 5.7 (starch) or 6.2-6.6 (other polysaccharides). Each experimental arrangement was incubated in four replicates.

\section{Chemicals}

Samples of monensin were donated by SPOFA - Research Institute of Feed Supplements and Veterinary Drugs, Jílové near Prague. Cellulose was added as a milled Whatman No. 1 filter paper. Hemicelluloses were isolated from wheat

Fig. 1. Effect of monensin on VFA concentration and molar ratio acetate to propionate in 20 $h$-cultures with rumen contents and cellulose $(3 \mathrm{~g} / 150 \mathrm{ml})$.

$\mathrm{A}=$ non - adapted wethers, $\mathrm{B}=$ adapted wethers, $\mathrm{a}=$ acetate, $\mathrm{p}=$ propionate, $\mathrm{b}=$ butyrate. Arrows indicate the VFA level at the beginning of the incubation.

*, ** - Total VFA values are significantly different from those of monensin - free control at $P<0.05$ and $P<0.001$, resp. 
VFA (nemil/I)

160

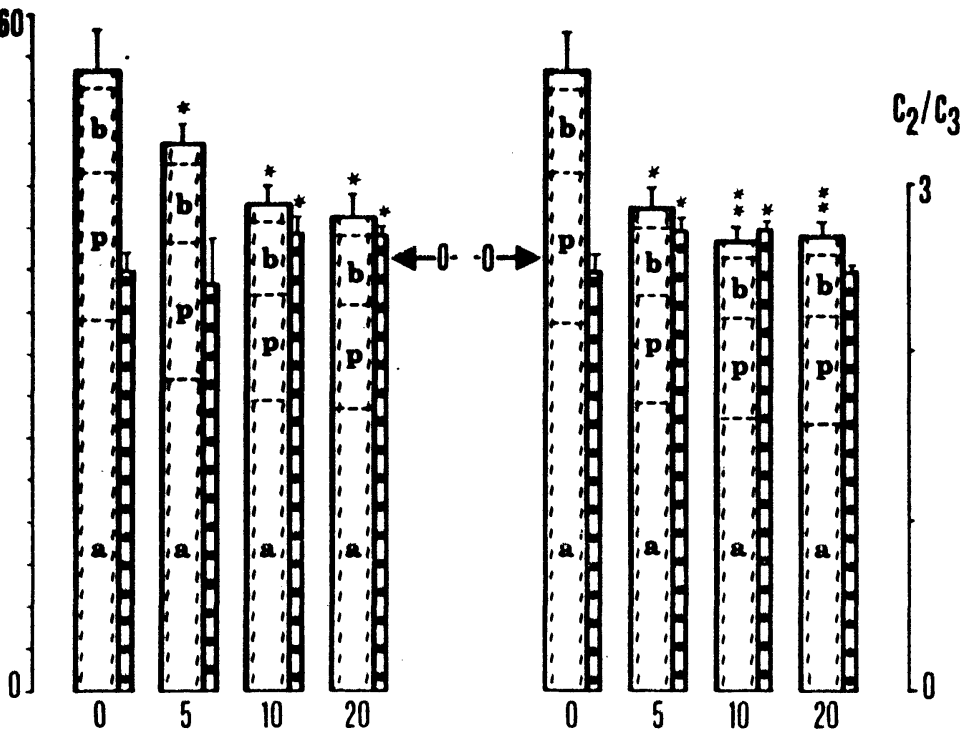

Fig. 1 
straw (Marounek et al. 1988). Citrus pectin was Genu Pektin from the Pectin Factory, Ltd., Copenhagen, commercial quality, methylation degree of $66.7 \%$. Maize starch came from Czechoslovak Starch Works. The other chemicals were supplied by Lachema, Brno.

\section{Analyses}

The $\mathrm{pH}$ of the incubation medium was measured at the beginning and end of an incubation. Total VFA were determined by titration, after steam distillation. Their molar composition was determined by gas chromatography on a column of the $\mathrm{N}$ - AW Chromaton with $10 \% \mathrm{SP} 1200$ and $1 \% \mathrm{H}_{3} \mathrm{PO}_{4}$; length $1.8 \mathrm{~m}$. The separation was carried out at $130^{\circ} \mathrm{C}$ with nitrogen $(150 \mathrm{kPa})$ as carrier gas.

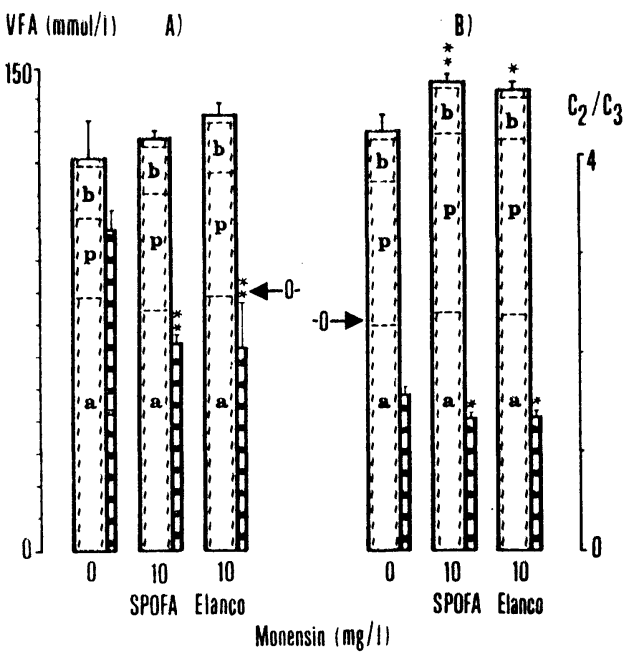

Fig. 2. Effects of monensin on VFA concentration and molar ratio acetate to propionate in $8 \mathrm{~h}$-cultures with rumen contents and hemicelluloses $(3 \mathrm{~g} / 150 \mathrm{ml})$.

$\mathrm{A}=$ non - adapted wethers, $\mathrm{B}=$ adapted wethers, $\mathrm{a}=$ acetate, $\mathrm{b}=$ butyrate, $\mathrm{p}=$ propionate. Arrows indicate the VFA level at the beginning of the incubation.

*, ** - Total VFA values are significantly different from those of monensin - free control at $\mathrm{P}<0.025$ and $\mathrm{P}<0.005$, resp.

\section{Results}

Our results are summarized in Figs. 1, 2, 3 and 4. Fig. 1 shows the effect of monensin on VFA concentration in cultures with cellulose as energy and carbon sources. The VFA concentration was lowered in these cultures by monensin, no matter whether the inoculum was taken from adapted or non-adapted wethers. On the other hand, there were only minor differences in total VFA concentration between monensin-free and monensin-treated cultures with hemicelluloses (Fig. 2), pectin (Fig. 3) and starch (Fig. 4).

Fig. 3. Effect of monensin on VFA concentration and molar ratio acetate to propionate in 6 h-cultures with rumen contents and pectin $(2 \mathrm{~g} / 150 \mathrm{ml})$.

$\mathrm{A}=$ non - adapted wethers, $\mathbf{B}=$ adapted wethers, $\mathrm{a}=$ acetate, $\mathrm{p}=$ propionate, $\mathrm{b}=$ butyrate. Arrows indicate the VFA level at the beginning of the incubation.

$*, * *$ - Total VFA values are significantly different from those of monensin - free control at $P<0.05$ and $P<0.005$, resp. 


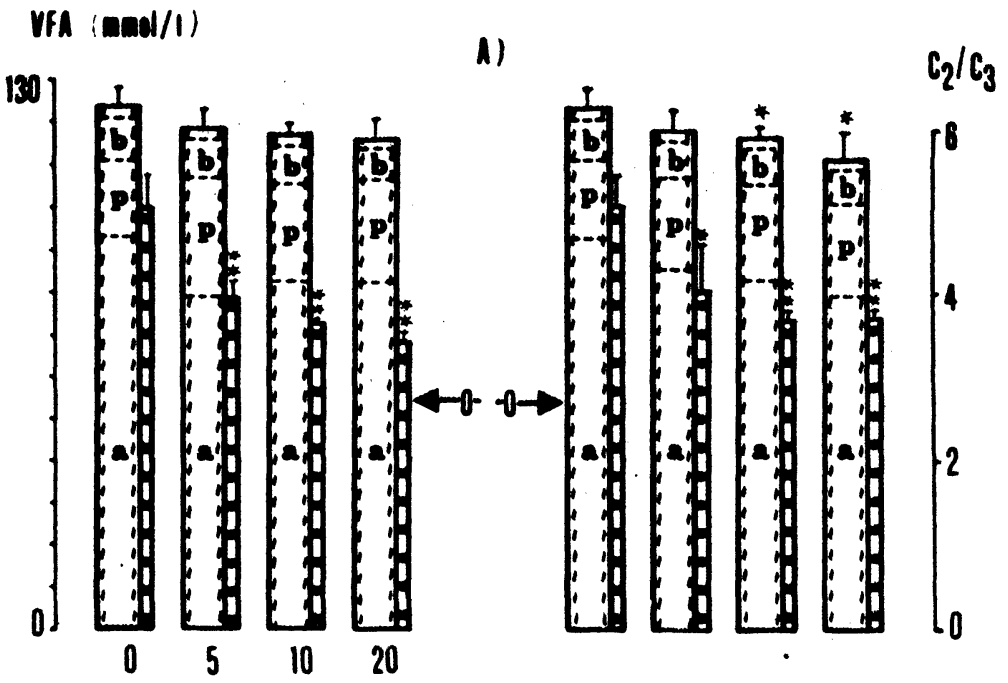

B)

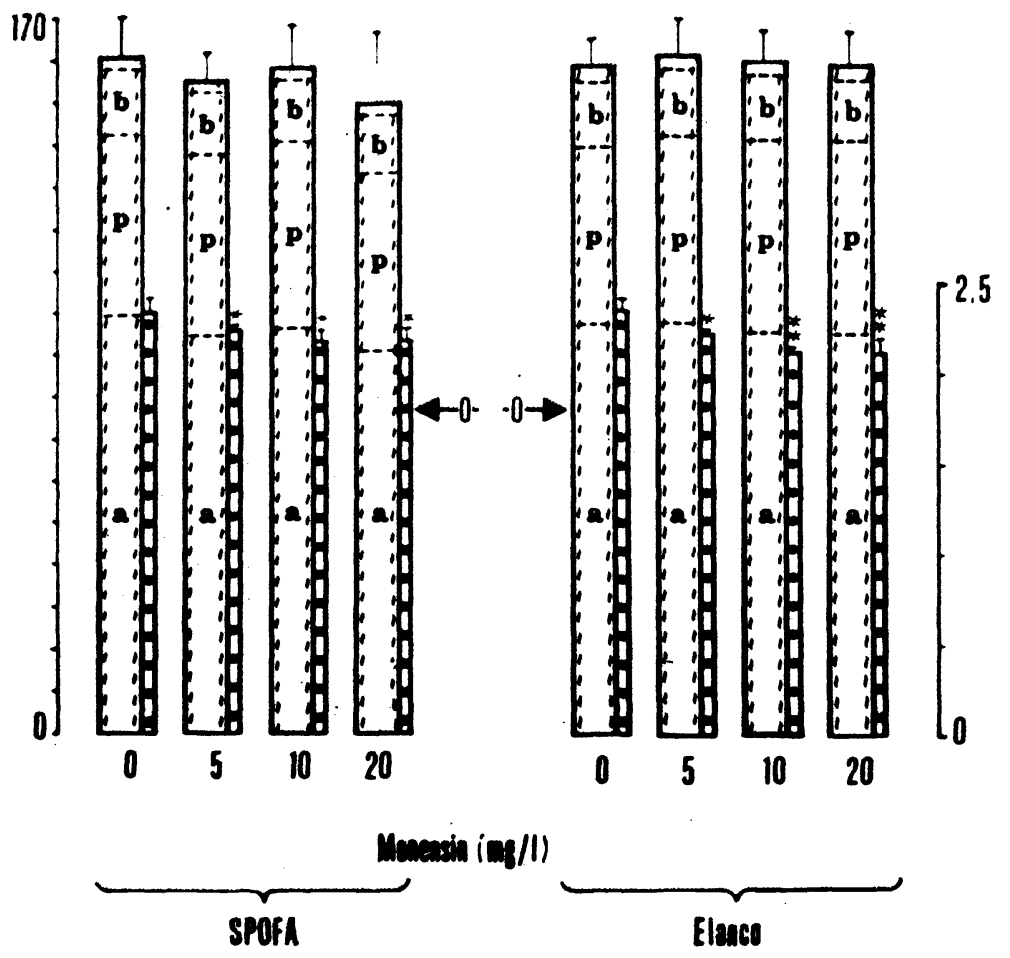

Fig. 3 
VFA (mand/i)

170

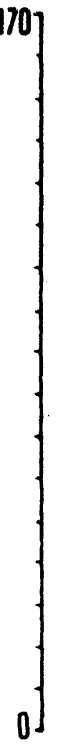

A)
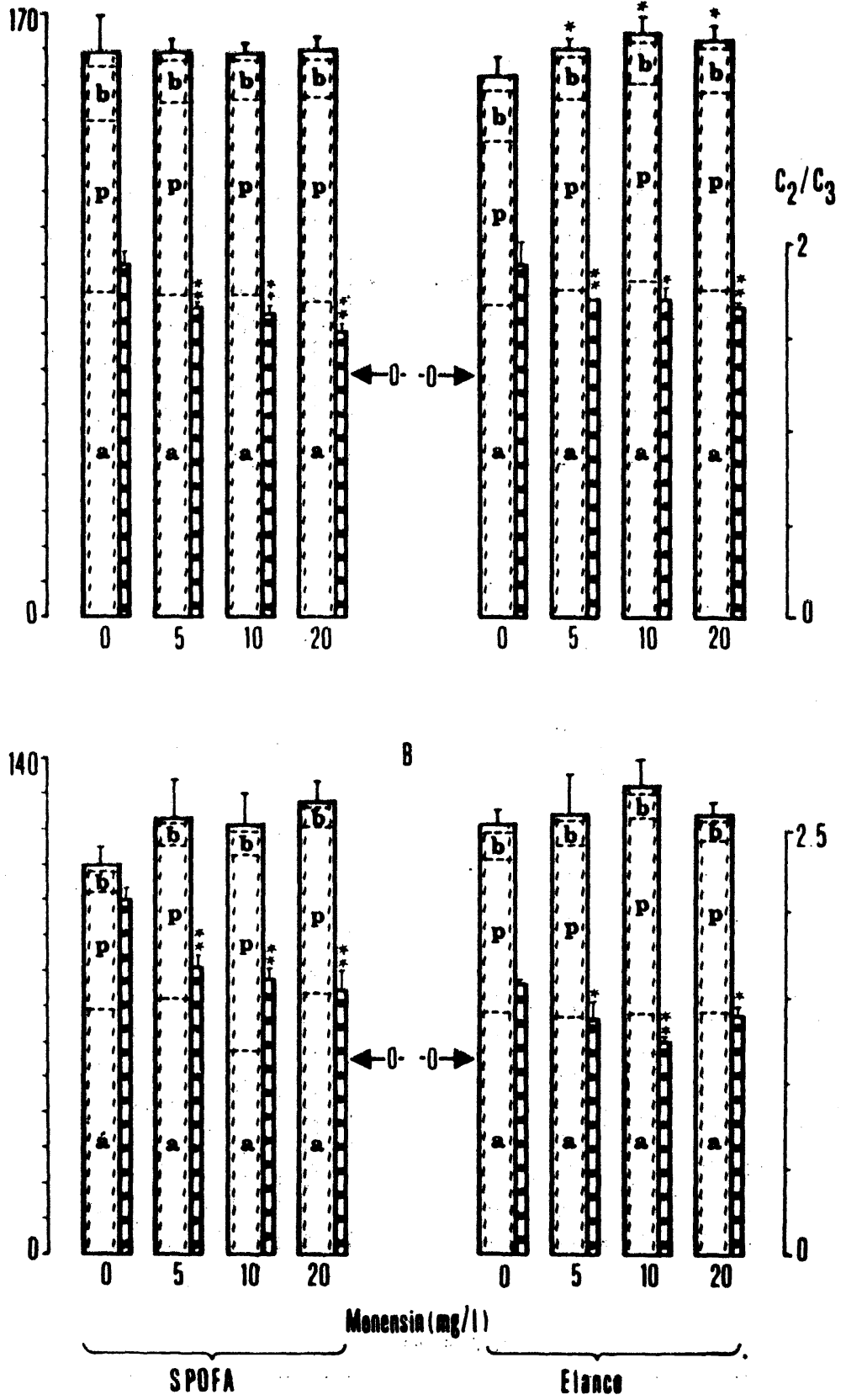

Fig. 4 
Monensin decreased the molar ratio acetate to propionate in cultures with hemicelluloses, pectin and starch (Figs. 2, 3 and 4). Contrary to this, in monensin-treated cultures with cellulose the ratio acetate : propionate was increased (Fig. 1).

There were no significant differences between monensin from Elanco and its Czechoslovak analogue in our experiments.

\section{Discussion}

It follows from our results that there are substantial differences between cellulose and other polysaccharides as far as monensin-induced metabolic shifts during fermentation are concerned. Our results support opinion of those authors who found that monensin depressed the fermentation of fiber and cellulose. The depression of fiber digestion can be reasonably explained by the inhibitory effect of monensin on rumen cellulolytic bacteria, mainly ruminococci and butyrivibria (Dennis et al. 1981; Henderson et al. 1981). As it is known that monensin increases the productive efficiency of ruminants on both high-concentrate (review Galyean and Owens 1988) and roughage diets (Potter et al. 1976; Faulkner et al. 1985), we must assume that unfavourable effect of monensin on digestion of cellulose is compensated for by its benefitial effect on digestion of other components of plant matter and/or by increased post-ruminal cellulose digestion.

Monensin-induced metabolic shifts were basically the same in cultures from non-adapted and adapted ( 2 months) animals. Latter contained higher proportion of propionate and lower acetate.

Účinek monensinu na produkci těkavých mastných kyselin z celulosy, hemicelulos, pektinu a škrobu ve směsných kulturách bachorových mikroorganismů

V pokusech in vitro jsme studovali účinek monensinu na produkci těkavých mastných kyselin (TMK) z celulosy, hemicelulos, pektinu a škrobu ve směsných kulturách bachorových mikroorganismů. Získali jsme tyto výsledky:

1. Monensin snižoval koncentraci TMK v kulturách $\mathbf{s}$ celulosou. $\mathrm{V}$ případě hemicelulos, pektinu a škrobu byly rozdíly celkových koncentrací TMK způsobené monensinem zanedbatelné.

2. Monensin snižoval molární poměr acetát : propionát $\mathrm{v}$ kulturách $\mathrm{s}$ hemicelulosami, pektinem a škrobem, avšak zvyšoval tento poměr v kulturách s celulosou.

3. Mezi monensinem Elanco a jeho čs. analogem nebyly významné rozdíly. Účinek monensinu trval v celém průběhu tříměsíčního pokusného období.

Fig. 4. Effect of monensin on VFA concentration and molar ratio acetate to propionate in 8 h-cultures with rumen fluid and starch $(3 \mathrm{~g} / 150 \mathrm{ml})$.

$\mathrm{A}=$ non - adapted wethers, $\mathrm{B}=$ adapted wethers, $\mathrm{a}=$ acetate, $\mathrm{p}=$ propionate, $\mathrm{b}=$ butyrate. Arrows indicate the VFA level at the beginning of the incubation.

*, ** - Total VFA values are significantly different from those of monensin - free control at $P<0.05$ and $P<0.001$, resp. 


\section{Воздействие монэнзина на продукцию летучих жирных кислот из целлюлозы, гемицеллюлозы, пектина и крахмала в смешанных культурах микроорганизмов рубца}

В ходе экспериментов ин витро проводили иоследования воздействия монэнзина на продукцию летучих жирных кислот (ЛЖК) из целлюлозы, гемицеллюлозы, пектина и крахмала в смешанных культурах микроорганизмов рубца. Нами были получены следующие результаты:

1) Монэнзин понижал концентрацию ЛЖК в культурах с целлюлозой. В случае гемицеллюлозы, пектина и крахмала разница общей концентрации ЛЖК, вызванная монэнзином, была ничтожной.

2) Монэнзин понижал молярное соотношение ацетат: пропионат в культурах с гемицеллюлозой, пектином и крахмалом, однако данное соотношение повышал в культурах с целлюлозой.

3) Между монэнзином Эланко и его чехословацким аналогом существенной разницы не наблюдали. Воэдействие монэнзина имело место в течение всепо трехмесячного экспериментального периода.

\section{References}

BEEVER, D. E. - LOSADA, H. R. - GALE, D. L. - SPOONER, M. C. - DHANOA, M. S.: The use of monensin or formaldehyde to control the digestion of the nitrogenous constituents of perennial ryegrass (Lolium perenne cv. Melle) and white clover (Trifolium repens cv. Blanca) in the rumen of cattle. Br. J. Nutr., 57, 1987: 57-67.

DENNIS, S. M. - NAGARAJA, T. G. - BARTLEY, E. E.: Effects of lasalocid or monensin on lactate - producing or - using bacteria. J. Anim. Sci., 52, 1981: 418-426.

DINIUS, D. A. - SIMPSON, M. E. - MARSH, P. B.: Effect of monensin fed with forage on digestion and the ruminal ecosystem of steers. J. Anim. Sci., 42, 1976: 229-234.

FAULKNER, D. B. - KLOPFENSTEIN, T. J. - TROTTER, T. N. - BRITTON, R. A.: Monensin effects on digestibility, ruminal protein escape and microbial protein synthesis on high - fiber diets. J. Anim. Sci., 61, 1985: 654-660.

GALYEAN, M. L. - OWENS, F. N.: Effects of monensin on growth, reproduction, and lactation in ruminants. In: ISI Atlas of Science: Animal and Plant Sciences, 1988: 71 -75.

HENDERSON, C. - STEWART, C. S. - NEKREP, F. V.: The effect of monensin on pure and mixed cultures of rumen bacteria. J. Appl. Bacteriol., 51, 1981: 159-169.

de JONG, A. - BERSCHAUER, F.: Adaptation effects of ionophores on rumen fermentation. S. Afr. J. Anim. Sci., 13, 1983: 67-70.

KOBAYASHI, Y. - WAKITA, M. - HOSHINO, S.: Effects of salinomycin on digesta passage, digestibility, nitrogen balance and ruminal traits in wethers. J. Anim. Physiol. a. Anim. Nutr., 56, 1986: 90-96.

LEBZIEN, P. - ROHR, K. - BREVES, G. - HÖLLER, H.: Untersuchungen über den Einfluss von Rumensin (Monensin - Natrium) auf die Stickstoffumsetzungen und die Thiaminnettosynthese in den Vormägen von Wiederkänern. J. Anim. Physiol. a. Anim. Nutr., 55, 1986: $177-186$.

MACKIE, R. I. - BAHRS, P. G. - THERION, J. J.: Adaptation of rumen bacteria to sodium and monensin. Can. J. Anim. Sci., 64 (Suppl.), 1984: 351-353.

MAROUNEK, M. - BARTOS,, S. - BREZINA, P.: Factors influencing the production of volatile fatty acids from hemicellulose, pectin and starch by mixed culture of rumen microorganisms. Z. Tierphysiol., Tierernährg. u. Futtermittelkde., 53, 1985: 50-58.

MAROUNEK, M. - KOPEČNÝ, J. - BARTOŠ, S. - BŘEZINA, P.: Isolation of wheat cellulose and hemicelluloses for in vitro studies on ruminal digestion. Sci. Agric. Bohemoslov., 20, 1988: 189-192.

POOS, M. I. - HANSON, T. L. - KLOPFENSTEIN, T. J.: Monensin effects on diet digestibility, ruminal protein bypass and microbial protein synthesis. J. Anim. Sci., 48, 1979: 1516 to 1524.

POTTER, E. L. - COOLEY, C. O. - RICHARDSON, L. F. - RAUN, A. P. - RATHMACHER, R. P.: Effect of monensin on performance of cattle fed forage. J. Anim. Sci., 43, 1976: $665-669$. 
WALLACE, R. J. - CZERKAWSKI, J. W. - BRECKENRIDGE, G.: Effect of monensin on the fermentation of basal rations in the Rumen Simulation Technique (Rusitec). Br. J. Nutr., 46, 1981: $131-148$.

WHETSTONE, H. D. - DAVIS, C. L. - BRYANT, M. P.: Effect of monensin on breakdown of protein by ruminal microorganisms in vitro. J. Anim. Sci., 53, 1981: 803-809.

ZINN, R. A.: Effect of salinomycin supplementation on characteristics of digestion and feedlot performance of cattle. J. Anim. Sci., 63, 1986: 1996-2004.

ZINN, R. A.: Influence of lasalocid and monensin plus tylosin on comparative feeding value of steam - flaked versus dry - rolled corn in diets for feedlot cattle. J. Anim. Sci., 65, 1987: $256-266$. 